\title{
Ecocritical Reunion of Man and Nature in The Ruined Cottage
}

\author{
Bazregarzadeh, E. \\ Graduate Student of English Language and Literature, Azarbaijan Shahid Madani University, Tabriz, IRAN. \\ Email: eli.b1988@gmail.com
}

\begin{abstract}
While the previous researches on Romanticism, especially Wordsworth (1770-1850), and Ecocriticism are quite far-ranging, the inherent ecocritical echoes of Wordsworth's oeuvre are yet to be surveyed. This study is an endeavor to examine the ecocritical aspects of William Wordsworth's The Ruined Cottage (1797-ca.1799) with the aim of bringing into focus the inner link between Nature and Ecocriticism in the above-mentioned poem. With that issue in mind, the researcher intends to take the viewpoints of the Yale School critics, the New Historicists, and those of the ecologists into consideration to prove the previous critics' inability in rendering a thorough reading of The Ruined Cottage and will examine the poem through the lens of Ecocriticism by focusing on the correspondence between the gradual withering of Nature and the gradual demise of Margaret's soul in order to reach a comprehensive examination of the poem in the end.
\end{abstract}

Keywords: The Ruined Cottage; Margaret; Soul; Nature; William Wordsworth.

\section{INTRODUCTION}

As a poet of Nature, William Wordsworth (17701850) valued physical Nature as a source of innocence, majesty, tranquility, dignity, and power that could relieve human psyche in all walks of life.To him, Nature was the mother and teacher of all mankind; the source of energy and emotions that was part and parcel of every human being's life. To Wordsworth, modernity and Industrial Revolution were synonymous with the destruction of the innocence and simplicity of the rural lifestyle. Previous critics of Wordsworth and his poetry have focused on the dichotomous nature of Wordsworth's poems resulting from their anti-Enlightenment tones and themes. As a result, they have failed to direct their attention to the environmental and ecological concepts embodied within the fabric of his poetry.

Since $19^{\text {th }}$ century, industrialization and scientific revolution have brought much improvement and convenience to the life of the individuals; they have also created a deteriorating atmosphere that is endangering the environment and the welfare of the creatures today. As Worster (1993) puts it, "We are facing a global crisis today, not because of how ecosystems function but rather because of how our ethical systems function" (p. 27). He furthermore declares:

Getting through the crisis requires understanding our impact on nature as precisely as possible, but even more, it requires understanding those ethical systems and using that understanding to reform them. Historians, along with literary scholars, anthropologists, and philosophers, cannot do the reforming, of course, but they can help with the understanding. (Worster, 1993, p. 27)

Therefore, it's time to improve the existing environmental problems through literature or other possible ways. In fact, the role of literature in environmental studies has gained much significance along with the advent of Ecocriticism. Glotfelty (1996), as the eminent scholar and founder of Ecocriticism in U.S., rejects the framework of the existing critical approaches in the following terms, "If your knowledge of the outside world were limited to what you could infer from the major publications of the literary profession, you would quickly discern that race, class, and gender were the hot topics of the late twentieth century"(p. $\mathrm{xvi}$ ). In the same manner, when it comes to the examination of other branches such as "history, philosophy, law, sociology, and religion,"Glotfelty (1996) argues that such trends and branches "have been "greening" since the 1970s," while "literary studies have apparently remained untinted by environmental concerns" (p. xvi). Though Ecocriticism emerged in the early 1990s, scholars of literature have been "developing ecologically informed criticism and theory since the seventies" (Glotfelty, 1996, p.xvi). Ultimately, the works of individual critics and 
scholars were grouped under one heading, i.e Ecocriticism; as a result, the "field of environmental literary studies was planted" and the "University of Nevada, Reno, created the first academic position in Literature and the Environment" (Glotfelty, 1996, p. xvii).

As a descendent of postmodern critical approaches to literature, Ecocriticism emerged in the 1990s with the aim of uprooting the current ecological emergency. The term Ecocriticism was coined by William Rueckert in his 1978 essay "Literature and Ecology: An Experiment in Ecocriticism" (as cited in Glotfelty, 1996, p. 105). The related term "ecological" was first used by the prominent US ecocritic Karl Kroeber (1974) whose essay, "Home at Grasmere" introduced explicitly ecological concepts to British Romantic Studies' (as cited in Hutchings, 2007, p. 196). Glotfelty (1996) believes, "ecocriticism is the study of the relationship between literature and the physical environment" which "takes an earth-centered approach to literary studies" (p. xviii) and answers such questions as, "What role does the physical setting play in the plot of this novel?, Are the values expressed in this play consistent with ecological wisdom?, and How can we categorize nature writing as a genre?" (Glotfelty, 1996, p. xix).

\section{METHOD}

Through an ecocritical examination of The Ruined Cottage (1797-ca.1799), the author aims to examine the way Wordsworth criticizes modernity and industrialization and will show how his poems develop ecocritical thinking as a call to social harmony, human-Nature reciprocity, and equilibrium.

\section{DISCUSSION AND ANALYSIS}

As was mentioned before, individual critics have talked about different aspects of Ecocriticism long before its coming into fruition as a unified critical approach. Despite theirseeming difference:

all ecological criticism shares the fundamental premise that human culture is connected to the physical world, affecting it and affected by it. Ecocriticism takes as its subject the interconnecttions between nature and culture, specifically the cultural artifacts of language and literature. As a critical stance, it has one foot in literature and the other on land; as a theoretical discourse, it negotiates between the human and the nonhuman. (Glotfelty, 1996, p. xix)

As a result, all ecological standpoints share one common belief: "the troubling awareness that we have reached the age of environmental limits, a time when the consequences of human actions are damaging the planet's life support systems" (Glotfelty, 1996, p. xix). The key to environmental problems is increasing our ecological mindsets to reach the recognition that Nature is not only "the stage upon which the human story is acted" but also "an actor in the drama" (Glotfelty, 1996, p. xix).

From the time Ecocriticism was established as a new theoretical approach, Romanticism, especially William Wordsworth, became the hot subjects of ecocritical studies. As a representative of the Romantic poets, Wordsworth composed many poems about plants, animals, and rural people which show his concerns for Nature. His poems were, in one way or another, a call to "eulogize nature" and to "encourage equality and harmony between nature and human beings" (Ting-ting \& Bin, 2014, p. 188). Wordsworth's views about Nature and natural elements have brought about many discussions between literary critics. Some tend to criticize him as a "philosophical" poet who "transcends human mind over nature" (Ho, 2002, p. 1). Others reject such views and believe that Wordsworth's glorifying Nature has been an effort to warn the people about "biocentrism" that Campbell (1989) defines as, "the conviction that humans are neither better nor worse than other creatures ... but simply equal to everything else in the natural world" (as cited in Glotfelty, 1996, p. 128).

There are three groups of critics examining the role of imagination and Nature in Wordsworth's poetry; the first of whom, the Yale School critics, maintain that Wordsworth used Nature to transcend his mind and imagination; the second of whom, the New Historicists, stress that Wordsworth valued poetic imagination to do away with history and society (Bate, 1991, p.8); the final group of critics, the ecocritics, assert that what Wordsworth did was creating a mutual relationship between man and Nature, i.e. symbiosis, in a sense, rejecting any hierarchy. As a Yale School critic, in his influential book Wordsworth's Poetry 1787-1814, Hartman (1987) asserts, it is "nature itself [that leads Wordsworth] beyond nature" (as cited in Ho, 2002, p. 1). He takes "the Simplon Pass" passage of Book six of The Prelude into account to reach the fact that "nature's 'end' is to lead to something 'without end,' to teach the travellers to transcend nature" (as cited in Ho, 2002, p. 1). Another Yale School critic, Bloom (1971), in The Visionary Company, mentions that the theme of Wordsworth' Tintern Abbey is "the nature of poet's imagination and ... imagination's relation to external Nature" (as cited in Ho, 2002, p. 1); as a result, he identifies Words- 
worth as a poet of imagination not of Nature. It is, therefore, this emphasis is on the imaginative mind that the New Historicists set themselves against.

The New Historicists tend to read the Romantic texts under the influence of Marxism; they focus on the Romantic's stress on human imagination and conclude that Romantics transcended human mind and imagination above Nature. According to Bate (1991), the New Historicists turn to "history" and "ideology": "The 1980s witnessed something of a return to history, a move away from ahistorical formalisms, among practitioners of literary criticism" (p.2). In his Wordsworth: The Sense of History, Liu (1989) accuses Wordsworth of concealing history. Liu took "The Simplon Pass" in Book six of The Prelude into consideration to claim, "[in] a Wordsworthian tour, the arrow of signification from historical ornament toward the background is curiously blunted: historical markers point nowhere and decorate nature for no purpose" (as cited in Ho, 2002, p. 2). In the same manner, he rejects Wordsworth's distorting the political issues of his time and laying emphasis on Nature instead by declaring, "[without] history in the background, a landscape, after all, is not a landscape; it is wilderness" (as cited in Ho, 2002, pp. 2-3). For such critics, Wordsworth's giving priority to his imagination was deemed as "a kind of compensation for his political disillusionment or even apostasy" (Bate, 1991, p. 3).

McGann (1983) criticizes Wordsworth from a sociohistorical point of view and asserts that Romantics render their ideas by "extreme forms of displacement and poetic conceptualization" which leads them to describe "idealized localities" (as cited in Ho, 2002, p. 3 ). He proposes that poetry is the product of social and historical events and should take socio-historical points into account. Also, he believes that Wordsworth created different artistic means to disguise the background of historical conditions. Therefore, he is bored with Wordsworth's "finding consolation in nature" rather than "attending to economic conditions" (Bate, 1991, p.15). In "The Anachronism of George Crabbe," McGann (1981) argues in The Ruined Cottage Wordsworth's relation with Nature highlights "compensatory justice", "Romantic Displacement", and "the 'fond illusion' of disastered things" (p. 570). Bate (1991) accuses McGann on the account of his neglecting "the transcendent imagination" in order to bring about the issues connected with "history" and "society". He believes, "The purpose which Jerome McGann wished to make Wordsworth serve in the historical circumstances of the early 1980s was the politicization of Romantic studies in the United States" (Bate, 1991, p. 5). By the same token, he rejects Hartman's criticism of Wordsworth due to his negligence of Wordsworth's strong connection with Nature to take "the transcendent imagination" into consideration (Bate, 1991, p. 8). Thus, Bate questions the tenets of the above-mentioned literary approaches as follows:

The 1960s gave us an idealist reading of Romanticism which was implicitly bourgeois in its privileging of the individual imagination; the 1980s gave us a post-Althusserian Marxist critique of Romanticism. The first of these readings assumed that the human mind is superior to nature; the second assumed that the economy of human society is more important than the "the economy of nature" (1991, p.9).

In line with that, Bate has reminded us of the fact that it is time for a new reading of Wordsworth, since "the best readings of classic texts are accordingly those which have both historical and contemporary force" (Bate, 1991, p. 9). He sheds light on "a green reading" of Wordsworth as an example, in as much as "it has strong historical force, for if one historicizes the idea of an ecological viewpoint . . . one finds oneself squarely in the Romantic tradition; and it has strong contemporary force in that it brings Romanticism to bear on what are likely to be some of the most pressing political issues of the coming decade" (Bate, 1991, p. 9).

In order to justify his new reading of Wordsworth, Bate casts doubt on the consistency of the previous readings of Wordsworth in the following terms:

Devout nineteenth-century reviewers used the discourse of religion when writing about Wordsworth; emancipated late twentieth-century critics use the discourse of feminism when writing about Romanticism: both then and now, elements of or absences from the poet's writings are emphasized in order to fulfil the specific polemical desires of specific readers. But in some readings - and I hope to show that my reading of Wordsworth is one of them - the critic's purposes are also the writer's, and when this is the case there can be a communion between living reader which may bring with it a particular enjoyment and a perception about endurance.(1991, p. 5)

Bate proposes that "the way in which William Wordsworth sought to enable his readers to enjoy or to endure life was by teaching them to look at and dwell in the natural world" (1991, p. 4).

Wordsworth's return to Nature has caused many critics to accuse him of neglecting the social and 
political issues of his time. By reading a great poem such as The Ruined Cottage, one can vividly see how he has masterfully employed the socio-political issues within the fabric of the poem. As Simpson (1987) clearly mentions in Wordsworth's Historical Imagination, Wordsworth's poems do certainly "address themselves to fairly precise events and circumstances," (as cited in Roberts, 2009, p. 54) such as war, disease, poverty, and so on and so forth. Furthermore, he believes that "death-dealing economic changes" such as "rural depopulation and the increaseing spread of mechanized labor and factory discipline . . . darkened his imaginative horizon" (Simpson, 2009, p. 1). For Simpson, Wordsworth was a figure who "had a profound poetic understanding of the condition of England around the 1800, specifically of its evolution into a culture governed by industrial time, machine-driven labor and commodity form" (2009, p. 4).

Wordsworth's The Ruined Cottage functions to instruct the readers how to "see into the life of things," (Wordsworth, 2006, p.1337, line.49) to perceive the importance of the bond between the rural poor and their ancestral land and to learn how to live in harmony with Nature. The narrative of the poem renders to the readers the facts of Margaret's "tale of silent suffering":

...'Tis a common tale,

By moving accidents uncharactered,

A tale of silent suffering, hardly clothed

In bodily form, and to the grosser sense

But ill adapted, scarcely palpable

To him who does not think. (Wordsworth, 2006, p. 1362, lines 231-236)

By focusing on agricultural blight, disease, and the collapse of textile industry, the poem depicts the decline of stability and familial life mirrored in the physical decomposition of the cottage:

The honeysuckle crowded round the door

And from the wall hung down in heavier wreathes,

And knots of worthless stone-crop started out

Along the window's edge, and grew like weeds

Against the lower panes. (Wordsworth, 2006, p. 1363, lines 308-312)

Economic decline gradually drives Margaret's husband, Robert, crazy and forces him to enlist in the forces then embroiled in the Napoleonic wars, leaving Margaret the enlistment pay in an ineffectual manner to ward off indigence:

He left his house; two wretched days had passed,

And on the third by the first break of light,

Within her casement full in view she saw

A purse of gold. (Wordsworth, 2006, lines 261264, p. 1362)
Margaret passes the days in anguish by importuning passers-by for news of his return until she gradually declines and dies. The ruin is the symbol of the radical socioeconomic changes of the 1790s. This period was a time of tumultuous social, political, and economic changes in England. According to Harrison (1994):

the high cost of war with France, poor harvests, enclosures and commercializations of all sectors of the economy brought spiralling high prices, large scale, agricultural unemployment, intermittent food shortages, social discontent and increasingly tense oppositions between a more highly organized right and left. (as cited in Roberts, 2009, p. 56)

Along with the advent new the modernized methods, those who opposed such trend were, as Williams (1978) notes, "ruthlessly broken down" (p. 61). McKusick (2000) explains the shift in agricultural tendencies in the following terms:

During the eighteenth century, the traditional methods of subsistence agriculture were gradually being supplanted, and the common areas upon which the local farmers relied for their seasonal grazing and gathering activities were increasingly being withdrawn for exclusive private use by the process of enclosure. (pp. 6364)

The high cost of agricultural commodities was due to the war and the rise in the population which forced the native farmers to sell their properties to make room for "the private farming enterprises that maximized output and profitability" (Roberts, 2009, p. 57). In opposition to the views of such New Historicist critics as McGann who argues that "In the course of the poem [The Ruined Cottage] not a word is said about the French Revolution, or about the impoverished and dislocated country poor, or-least of all - that this event and those conditions might be structurally related to each other" (as cited in Huang, 2001, p. 3), McKusick (2000) asserts that "Wordsworth was truly ahead of his time, and radically innovative in his concern for the preservation of the traditional rural ways of life, the homeless, and all the wild creatures that dwell beyond the pale, outside the conventional boundaries of human civilization" (p. 65). Read critically and thoroughly, one can get to the point that the poem is "as much about the narrating of a tale as the tale itself" (Larkin, 2000, p. 348). Wordsworth's awareness about the hot social, political, and economic issues of his time is the key to his being known as "the apologist for locality and local loyalty . .. praising the rural life of the individuals and decrying the depersonalized life of people in industrialized cities" (Pite, 1996, p. 366). His main 
concern at the time of composition of this poem has been the collapse of the textile industry which brought a shift from "hand labour" to "mechanized production" (Roberts, 2009, p. 57). Prior to mechanization, families earned their livings through in-house production of wool and cloth which served as an extra source of income in addition to their drawing their livelihood from small farms and fields. After the collapse of in-house textile industry, families were deprived of this revenue and had to adapt themselves to the controlling conditions, which in some cases removed them from their land (Roberts, 2009, p. 57).

In The Ruined Cottage, Wordsworth comments not only on the misfortunes of the poor, but also on the impact of the social, political, and economic changes of the 1790s on the relationship of the individuals with Nature and their subsequent removal from their ancestral land. The decline of one peasant family's bond with Nature is the main focus of the poem. The physical decay of the cottage, the people, and their bodies, are the result of social disasters, especially the collapse of the textile industry on which they depended for livelihood. As the narrator, the Pedlar, tells the Wanderer, in their happier days Margaret and Robert lived in sync with Nature. As a weaver, Robert was:

$\ldots$ an industrious man,

Sober and steady; I have heard her say

That was up and busy at his loom

In summer ere the mower's scythe had swept

The dewy grass, and in the early spring

Ere the last star had vanished. (Wordsworth, 2006, p. 1359, lines 120-12)

Prior to the social and economic hardships, Robert's labour was attuned to the seasonal changes of Nature. Later, when ". . . shoals of artisans / Were from their daily labour turned away," Robert fell out of harmony with Nature: ". . . with a strange, / Amusing but uneasy novelty / He blended where he might the various tasks / Of summer, autumn, winter, and of spring" (Wordsworth, 2006, p. 1360, lines 154-171).

The disturbance in the pattern of his work is a manifestation of the madness that befalls him as a result of the collapse of the textile industry. In addition to the decline of the textile industry, other dilemmas afflict Robert and his family; "two blighting seasons when the field were left with half a harvest," and the "plague of war" and following these, Robert and Margaret's illnesses (Wordsworth, 2006, p. 1360, lines 133-136). These predicaments diminish the couple's resources to the extent that after Robert's recovery from a long illness he finds ". . . the little he had stored to meet / The hour of accident or crippling age / Was all consumed" (Wordsworth, 2006, p. 1360, lines 151-153). As the breadwinner of the house, Robert, like many other men, relied on his loom to earn money to support his family. As a result of the decline of the industry, the family was deprived of a key source of income. Prior to this event, "numerous self-denials" protected Margaret and her family from "calamitous years" of disease and hardship. But, later, the socio-economic problems led them to rely on "parish charity" for survival. Robert's alienation from Nature is shown in his strange behaviour towards his family. The very "industrious man" who worked "up and busy at his loom," now deprived of a reliable industry sinks down in spirit and begins to "carve uncouth figures on the heads of sticks" (Wordsworth, 2006, p. 1360, line 165). The same hands that worked in harmony with the diurnal rhythms of Nature, disorder the "various tasks of summer, autumn, winter, and of spring" (Wordsworth, 2006, p. 1360, lines 170-171). As Harrison (1994) claims, "we could say that Robert has fallen from . . . the self regulating order of nature" (as cited in Roberts, 2009, p. 61). As a result, ". . . poverty brought on a petted mood / And a sore temper: day by day he drooped" (Wordsworth, 2006, p. 1360, lines 174-175).

The word "droop" is of key importance here, since the narrator uses it to describe Margaret's condition after Robert's enlistment in the army too. In lines 394396, the narrator explains Margaret's emotional decline as, "Ere on its sunny bank the primrose flower / Had chronicled the earliest days of spring. / I found her sad and drooping". As shown in the poem, the season is spring, the time of rejuvenation and regrowth. Thus, Margaret's drooping is totally out of tune with Nature and the natural order and leads to her separation from Nature. Margaret's alienation from Nature is consistent with the physical decline of the cottage. The Pedlar first perceives its change in the "worthless stonecrop" that "started out along the window's edge like weeds"; "honeysuckle crowded round the door" in "heavier tufts"; the "straggled" appearance of the garden beds (Wordsworth, 2006, p. 1363, lines 308-319). Such changes mirror Margaret's emotional deterioration. Like the rose "dragged from its sustaining wall and bent down to the earth" by "unwieldy wreaths" of weeds, she "droops" in despair (Wordsworth, 2006, p. 1363, lines 308-319).The "sustaining wall" is a rich image; it can be Robert for whom she sinks down in spirit, or Nature and traditions of rural life, or, more importantly, the cottage itself. As Fosso (1995) notes, Margaret is caught between uncertainties; she is not sure whether her husband is alive or he is dead, hence she cannot make up her mind if she should mourn the death of 
her pillar of reliance or not (as cited in Roberts, 2009, p. 62). Hence, she is both "a wife and a widow" (Wordsworth, 2006, p. 1366, line 448).

The emotional trauma of her uncertainty and abandonment as a result of her "being dragged from" the "sustaining wall" of her husband "bends her down to the earth," in which she must toil to live. Formerly, she is seen "busy with her garden tools," (Wordsworth, 2006, p. 1363, line 283) but as poverty increases her cottage and garden are given over to the "sleepy hands of neglect" (Wordsworth, 2006, p. 1363, line 401). However, her degeneration stems most from the family's being "pulled from" the "sustaining" embrace of Nature. Such disintegration, followed by their detachment from their "sustaining" work, "bends her down to earth" which leads to the decaying appearance of the cottage. Her separation from Nature is seen in the "unwieldy wreaths" of weeds that eat up the "sustaining walls" of her cottage. She has lost her meaningful and conscious connection with the powers and processes of Nature and becomes idle like the garden and the cottage. Nature works on her instead of working in and through her and Margaret becomes the subject of decay. This is seen in the rapid collapse of the hut, which "reft" by "frost, and thaw, and rain" (Wordsworth, 2006, p. 1363, line 482) is choked with unruly elements. Nevertheless, Margaret remains disassociated, even as "her tattered clothes" are "ruffled by the wind" at "the side of her own fire" (Wordsworth, 2006, p. 1363, lines 485-486). As Swann (1991) in "Suffering and Sensation in The Ruined Cottage" claims, such issues are the symbols of a society "that is afflicted by the economic crisis and the attendant alienated aesthetics that Wordsworth associates with modernity" (p. 92).

As mentioned before, different critics have different opinions about the effects of the economic hardships on the life of Robert and Margaret. According to Harrison (1994), "the loss of their imaginative sympathy with nature ultimately destroys the spiritual integrity and mental health of both Margaret and Robert" (as cited in Roberts, 2009, p. 64). Margaret and Robert's economic and psychological declines bring about their disintegration from Nature. Caught in "poverty and grief", Margaret ceases to tend her garden to the degree that no "ridges" of "clear black mould nor winter greenness" (Wordsworth, 2006, p. 1365 , line 416) is manifested to the Pedlar's eyes. The disappearance of mould, tilled soil, bespeaks the loss of harmony between the cultivator and the land. Like Robert, Margaret's hands are deprived of their coordination with Nature and, thus, become "sleepy" and "negligent". Accordingly, Margaret takes to wandering the fields, often with the hope of not getting back; ". . . I've wandered much of late, / And sometimes, to my shame I speak, have need / Of my best prayers to bring me back again" (Wordsworth, 2006, p. 1364, lines 341-343). Having lost her contact with the natural rhythms of life, Margaret remarks, "Weeping, and weeping I have waked; my tears / Have flow'd as if my body were not such / As others are, and I could never die" (Wordsworth, 2006, p. 1364 , lines 355-357). Such a statement is the signifier of Margaret's doubt about her mortality; she thinks as if she was a ghost. Her face grows "pale and thin" (Wordsworth, 2006, p. 1364, line 358). During his last visit, the Pedlar claims, "... Her voice was low, / Her body was subdued . .." and when she sighed ". . . no motion in the breast was seen, / No heaving of the heart. .." (Wordsworth, 2006, p. 1365, lines 379-384). She lingers on till she dies, "Last human tenant of these ruined walls" (Wordsworth, 2006, p. 1367, line 492).

Besides the above-mentioned points, Margaret's physical death is actually a reunion with the earth. The Pedlar's lament ". . . She is dead, / The worm is on her cheek" (Wordsworth, 2006, p. 1359, lines 103104) can be read ironically in that through the process of decomposition, Margaret's body changes into mould which shows her union with the natural rhythms of life. As the narrator argues bodily integration with Nature is good as far as it is the ". . . secret spirit of humanity", which persists ". . . 'mid the calm oblivious tendencies / Of nature" (Wordsworth, 2006, p. 1367, lines 503-504). This, in fact, echoes Bate's (1991) comment, "humanity only survives in nature. Human survival and the survival of nature are therefore co-ordinate with one another" (Bate, 1991, p. 34). Consistent with the final decay of the hut, the narrator notes no monument is left of the people. The house in its present condition is "four naked walls" (Wordsworth, 2006, p. 1357, line 31) and the only sign of human presence is "The useless fragment of a wooden bowl" (Wordsworth, 2006, p. 1359, line 91). "And nettles rot and adders sun themselves" on the bench where, in happier times, Margaret nursed her infant baby; and, in the sober time, awaited the arrival of her husband (Wordsworth, 2006, p. 1363, lines 109-110). The unpleasant deteriorating condition of the time gives rise to:

... that which each man loved

And prized in his peculiar nook of earth

Dies with him or is changed, and very soon

Even of the good is no memorial left. (Wordsworth, 2006, p. 1358, lines 69-72)

Margaret's return to the earth can be considered as a kind of "redemption" through reconnection with 
Nature. In the opinion of Roberts (2009), The Ruined Cottage:

is not merely the story of the senseless tragedy of a people. Rather, it affords an opportunity for the reader to contemplate a more harmonious connection for themselves with nature. The potential for her story to transform the readers think about their relation to the environment is evident in the change that takes place in the narrator from beginning to the end of the poem. (p. 67)

By analysing the poem, we can understand that the narrator enters the poem in an agitated spirit. $\mathrm{He}$ is seen wandering along a barren landscape and he is not able to make his way through the plain as his "languid feet" are "baffled still" by the "slipp'ry ground" (Wordsworth, 2006, p. 1357, lines 20-21). He is at first so much out of tune with Nature that he cannot make himself at home with the natural elements. In contrast to this image, the narrator describes the old man, Pedlar, as a "dreaming man" who "Halfconscious" enjoys "that soothing melody," in the embrace of Nature (Wordsworth, 2006, p. 1357, lines14-15). The juxtaposition of these two different reactions to Nature echoes Averill's (1976) viewpoint which suggests that "internal psychological factors are largely responsible for his being out of tune with his surroundings and that the weariness is rather a more spiritual than a physical state" (as cited in Roberts, 2009 , p. 68). Nature is not, inherently, at odds with the Wanderer, rather this view is the outcome of his mentality towards Nature. Despite the narrator's subjective view at the beginning of the poem, his perspective goes through a major change from disquietude to "harmony" by the end of the poem.As Averill (1976) reveals, it is a change from "paranoid irritability" to a "sense of universal well-being" as a result of hearing and meditating on Margaret's story (as cited in Roberts, 2009, p. 69).

Consequently, Nature plays the role of a healing agent in the poem and soothes the bleak tragedy of the dead through the notion of spiritual redemption. By the end of the poem, it becomes clear that the cottage is the symbol of a decaying life, on the one hand, and the renewing of a harmonious bond with Nature, on the other. In fact, the poem is a manifestation of "exploration of human nature at the fringes of civilization" (Meldahl, 2007, p. 9). It throws light on the possibility of the maintenance of harmony between internal nature and external Nature despite the seeming plights. A careful analysis of the poem counters the critical stances of such critics as Liu and McGann (2001), who accuse Wordsworth of not placing his poems in the historical contexts. McGann considers this point as, "the deepest and most piteous loss" and Liu clarifies this notion as, "No jewel without its setting: without history in the background, after all, a landscape is not a landscape; it is wilderness" (as cited in Huang, 2001, p. 4). In opposition to such views, Bate (1991) holds that "the 'Romantic Ideology' displaces and idealizes, it privileges imagination at the expense of history, it covers up social conditions as it quests for transcendence" (p. 6).In fact, the New Historicists do not oppose the transcendental theory of their predecessors, the Yale School critics; rather they base their points on this premise. What they rise against is that they blame Wordsworth of neglecting history, to which the Yale critics did not pay much attention at the time of analysing Wordsworth critically. So, they not only opposed the idea of individual imagination, but also the Yale School hegemony:

[The Romantic Ideology] served a purpose, namely to offer a challenge to the hegemony which idealizing, imagination-privileging critics like Geoffrey Hartman and Harold Bloom had held over Romantic studies in the United States for twenty years, in particular through their hugely influential books, Wordsworth's Poetry and The Visionary Company. (Bate, 1991, p. 6)

Despite their differences, the New-Historicists and the Yale School critics believe that, to Wordsworth, individual transcendence is of primary importance and he uses Nature to transcend his own mind. Kroeber (1974) summarizes their similarities in terms of two points; "first, that romantic poets regarded private consciousness as distinct from and superior to all natural phenomena" and "second, that the poets regularly sought to transcend, if only linguistically, the physical circumstances of their experiences in the natural world" (as cited in Huang, 2001, p. 7).

The researcher holds that Wordsworth does not go beyond Nature; rather he dwells in Nature, communes with it, and learns from it. He has a holistic view towards Nature. According to Dunklin (1948), Wordsworth tends to "see life steadily and to see it whole," and this notion stems from "an outworn mode of regarding man, nature, and society which he had inherited from the eighteenth century that was fascinated by the concept of the great chain of being" (as cited in Huang, 2001, p. 8). Therefore, instead of regarding the relationship between man and Nature as antagonistic, Wordsworth tries to build a close relationship between man and Nature, in his poems, through feelings and emotions. As Kroeber (1974) mentions:

Cold war critics [New Historicists] under the antagonistic oppositionalism, and conceiving 
relationships exclusively in terms of power struggles, tend to treat all poems as lyricized representation of 'primal scenes,' that is, as schematic dramatizations of universal psychic conflicts. (as cited in Huang, 2001, p. 10)

In line with Kroeber, Bate (1991) believes that "there is not an opposition but a continuity between his [Wordsworth's] 'love of nature' and his revolutionary politics" (p.10). While Liu (1989) asserts that "there is no nature except as it is constituted by acts of political definition made possible by particular forms of government" (p. 15), Bate responds:

But here one sees the limitation of Liu's argument: not even the most ardent advocate of entrepreneurship and the free market can privatize the air we breathe. Governments may legislate about what we emit into the air, and in the sense that constitution of nature is determined by government and industry, but we cannot parcel out the air as we parcel out the land. And water can only be privatized in a limited sense. The particles of water which form clouds - and we need no reminding of how important clouds were to Wordsworth . . . cannot be possessed or sold. (1991, p. 19)

\section{CONCLUSION}

As explained above, The Ruined Cottage can be regarded as a reliable example of Wordsworth's internal bond with Nature. Though the plot of the poem renders a tragic story on the surface, it unveils the hidden themes that may not be easily apparent to all the readers if we read it deeply. By witnessing the continuity of the natural processes in Margaret's garden one may think that Nature does not care about man and is oblivious of his/her suffering. Paradoxically the continuation of natural rhythms brings the notion of survival to our minds. Although the cottage and the garden are fed up with the spear-grass and wilderness, one should also notice the impression that "where wilderness reasserts itself there the spirit of humanity survives" (Bate, 1991, p. 34). As Nayak (1993) maintains, Wordsworth is a poet of "human life" (p. 153). Wordsworth's poetry, from the outset, dealt with "deprivations, sufferings and fortitude" (Nayak, 1993, p. 155). He teaches human beings how to endure sufferings and hardships, since "man's capacity for pain is as inexhaustible as his ability to endure. His vulnerability is co-extensive with the experience to which his is exposed" (Nayak, 1993, p.154). Margaret is deserted by her husband; her family life and natural surroundings sink down: "No ridges there appeared of clear black mould, / No winter greenness. .." (Wordsworth, 2006, p. 1365, lines 416-417); but Margaret hopes for her husband's return, ". . . in the stormy day / Her tattered clothes were ruffled by the wind / Even at the side of her own fire. /. . .Yet still / She loved this wretched spot, nor would for worlds / Have parted hence. . . (Wordsworth, 2006, p.1367, lines 484-488). As a result, Wordsworth intends to show the value of the survival of humankind in Nature in the way that Bate (1991) remarks, "the survival of humanity comes with nature's mastery over the edifices of civilization" (p.34). In short, Wordsworth teaches human beings how to "discover the one behind the many, the eternal behind the transitory, [and] the perfect behind the incomplete" (Nayak, 1993, p. 159).

\section{REFERENCES}

Averill, J. H. (1976). Suffering and calm in Wordsworth's early poetry. PMLA 91(2), 223-234. Retrieved from http://www.jstor.org/stable/461 509.

Bate, J. (1991). Romantic ecology: Wordsworth and the environmental tradition. London: Routledge.

Bloom, H. (1971). The visionary company. New York: Cornell University Press.

Campbell, S. E. (1989). The land and language of desire. In. C. Glotfelty, \& H. Fromm (Eds.), The ecocriticism reader: Landmarks in literary ecology. (pp. 124-136). Athens: University of Georgia Press.

Dunklin, G. T. (1948). Wordsworth's theory of education. Diss. Retrieved from http://www. researchgate.net/publication/35859216_Wordsw orth's_theory_of_education

Fosso, K. (1995). Community and mourning in William Wordsworth's the ruined cottage 17971798. Studies in Philology 92(3), 329-345. Retrieved from www.jstor.org/stable/4174522

Glotfelty, C. (1996). Introduction. In. C. Glotfelty, \& H. Fromm (Eds.), The ecocriticism reader: Landmarks in literary ecology (pp. xvi-xix). Athens: University of Georgia Press.

Harrison, G. (1994). Wordsworth's vagrant muse: Poetry, poverty, and power. Detroit: Wayne State University Press.

Hartman, G. H. (1987). Wordsworth's Poetry: 17871814. Massachusetts: Harvard University Press.

Ho, Y. C. (2002). Wordsworth's ecological concepts. (Unpublished master's thesis). Retrieved from http://etd.lib.nsysu.edu.tw/ETD-db/ETD-search/ view_etd?URN=etd- 0902102183055

Huang, Y. H. (2001). Wordsworth and nineteencentury English educational reform. Retrieved from http://etd.lib.nsysu.edu.tw/ETD-db/ETDsearch/view etd?URN=etd-0822101-145855 
Kroeber, K. (1974). Home at Grasmere: Ecological holiness. PLMA 89, 132-141. Retrieved from www.jstor.org/stable/461676

Larkin, P. (2000).Relations of scarcity: Ecology and eschatology in the ruined cottage. Studies in Romanticism 39(3), 341-364. Retrieved from www.jstor.org/stable/25601455

Liu, A. (1989). Wordsworth: The sense of history. Stanford: Stanford University Press.

McGann, J. J. (1981). The anachronism of George Crabbe. ELH 48(3), 557-572. Retrieved from www.jstor.org/stable/2872913

McGann, J. J. (1983). Romantic ideology: A critical investigation. Chicago: University of Chicago Press.

McKusick, J. C. (2000). Green writing: Romanticism and ecology. New York: St. Martin's Press.

Meldahl, G. L. (2007). Religion and renunciation in Wordsworth: The progression of natural individualism to Christian stoicism. Retrieved from http://digitalcommons.colby.edu/honorstheses/2 791

Nayak, P. M. (1993). Celestial infancy and other essays on Wordsworth. New Delhi: Anmol Publications.

Pite, R. (1996). How green were the romantics. Studies in Romanticism 35(3), 357-373. Retrieved from www.jstor.org/stable/25601179

Roberts, H. M. (2009). Seeing green: Nature and human relationships with the environment in Wordsworth. Retrieved from http://www.dissertations.wsu.edu/Thesis/Spring2009/h_roberts_0 50209.pdf

Rueckert, W. (1996). Literature and ecology: an experiment in ecocriticism. The ecocriticism reader: Landmarks in literary ecology. In. C.
Glotfelty, \& H. Fromm (Eds.), The ecocriticism reader: Landmarks in literary ecology (pp. 105122). Athens: University of Georgia Press.

Simpson, D. (1987). Wordsworth's historical imagination: The poetry of displacement. New York: Methuen.

Simpson, D. (2009). Wordsworth, commodification, and social concern. New York: Cambridge University Press.

Swann, K. (1991). Suffering and sensation in the ruined cottage. PLMA 106(1), 83-95. Retrieved fromwww.jstor.org/stable/462825

Ting-ting, Yang, and Xiao, B. (2014).A deep ecological reading of William Wordsworth's poetry. Sino-US English Teaching 11(3), 188195.

Williams, R. (1978). The country and the city. New York: Oxford University Press.

Wordsworth, W. (2006). The ruined cottage. In M. H. Abrams, E. T. Donaldson, A. David, H. Smith, B. K. Lewalski, R. M. Adams, ... J. Stallworthy (Eds.), The Norton anthology of English literature, the major authors. $\left(7^{\text {th }}\right.$ ed., p. 14641474). New York, NY: W. W. Norton \& Company, Inc.

Wordsworth, W. (2006). Lines composed a few miles above Tintern Abbey. In M. H. Abrams, E. T. Donaldson, A. David, H. Smith, B. K. Lewalski, R. M. Adams, ... J. Stallworthy (Eds.), The Norton anthology of English literature, the major authors. ( $7^{\text {th }}$ ed., p. 1336-1339). New York, NY: W. W. Norton \& Company, Inc.

Worster, Donald. (1977). Nature's economy: The roots of ecology. San Francisco: Sierra Club Books. 